\title{
THE OPTIMIZATION OF RAILWAY TRANSPORTATION MODES TO REDUCE COSTS AND SUPPORT LOGISTICS ACTIVITIES
}

\author{
Rendy Prabowo ${ }^{1}$ \\ 1.STMT Trisakti \\ Corresponding Author: rendyprbw@gmail.com
}

\begin{abstract}
Logistics is inseparable with transportation because it aims to support the logistics activities. Truck transport still becomes the main choice in supporting logistics activities though it is expensive and risky. Besides truck, railway transportation is a solution for logistics that can provide a rail based on freight train services which is cheap and quick. The lightweight of actual operation process that is suitable for shipping is less than $350 \mathrm{KM}$. On the other hand, rail transport is an efficient transportation for delivery of goods more than $350 \mathrm{KM}$. The purpose of this research is to investigate the optimization of railway transport modes to reduce cost and support logistics activities to be more efficient in Indonesia.
\end{abstract}

Keyword: Railway transport and Logistics

\section{Introduction}

Transportation is an important element for people's lives. Transportation mobilizes goods and the society as well. Logistics activity is inseparable with transportation. So far to support logistics activitiy Indonesia has been relying on trucking for land transportation and ships for the sea transportation, considering that Indonesia is a vast archipelagic country.

The main objective in the development of national logistics system (SISLOGNAS) is delivering goods effectively and efficiently by using national infrastructure in its activities. However some unwanted situations occur in Indonesia on the island of Java. It happens because the logistics business actors keep using the truck as the main choice in the process. Fortunately, there is other transport that is much faster and cheaper for the delivery of goods widely. It is the rail transport.

Currently, based on Central Bureau of Statistics (BPS) railway freight users in Indonesia are only $31.46 \%$. Some logistic entrepreneurs are reluctant to use rail transport due to some reasons. The railway presumption is much more expensive than trucks, trains can not do door-to-door delivery, and railroad policy makes it difficult if people want to use a train (Wibowo, 
2016). On the other hand the railway transport is very much expected to support the process of delivery. The lack of innovation by PT Kereta Api Logistik (KALOG), a subsidiary of PT.Kereta Api Indonesia (KAI), is the main cause of the reluctance of logistic and industry players to use freight rail services (Kayikci, 2010). During this time, commodities that often use the freight services are coal and general cargo, while small goods, such as automotive parts or vehicles that still rarely use freight trains.

Actually, this is the opportunity for PT.KAI to develop automotive industry in Indonesia. The main problem is the lack of innovation from railbased freight services provider. Because of the problem, the author is interested to write scientific papers with the topic "The Optimization of Railway Transportation Modes to Reduce Costs and Support Logistics Activities."

This study can be identified as follows:

a. The absence of trust of logistics business actors nor industry to use freight trains to support distribution activities.

b. Railways can not do door-to-door service.

c. Trains are much more expensive than trucks.

d. Lack of innovation by PT.KAI to utilize the opportunities.

1. Subject matter

a. How much does the railway shipping cost compare to the truck cost?

b. What innovation should be done by PT. Kereta Api Logistik in facing the market needs?

2. Research Objectives

a. To know the ratio of shipping cost between train and truck.

b. To know what innovations to be done by PT.Kereta Api Logistik to face the market needs.

\section{Method}

This study used descriptive explorative method. The research aims to describe a phenomenon or circumstances carefully (Sugiyono 2015: 23). In 
the study the author combined descriptive explorative method with comparative descriptive. According to Sugiyono (2015: 25) comparative descriptive is a study that compares things and to know things that relate to the happening circumstances. In this study, research phenomenon serves as the basis tool for research. The analyzed data was obtained by in- depth interview (Rifni and Prasetya, 2016)

\section{Discussion and Results}

Siregar (2004: 64) defines optimization as a management of work process that aims to optimize the needed potential, location, value, amount or volume while according to Indonesian Dictionary, it is a process that elevates or improves.

The main problem faced by PT.KAI is the lack of innovation in increasing the capacity for rail and the model of wagon for freight transport. According to Stephen Robins, innovation is a new idea applied to initiate or improve a product and service. It is not unreasonable that the current emerging industry is the automotive industry. Although at the beginning of 2016, there were several automotive industries that closed down their factories in Indonesia, it does not mean the automotive market in Indonesia is lethargic. It happens because of business competition. So far, the automotive industry players in the distribution process have been relying heavily on trucks as the main transportation for product distribution. In addition to the model of wagons that can only be used to make general cargo shipments and not being able to support the delivery of vehicles or automotive, cost factors are also a consideration for these business actors. Actually this is an opportunity that can be taken by PT.KALOG because not only the automotive industry, all industries require transportation for the distribution process.

The role of land transportation has an important and strategic position, the policy making of land transportation management needs to be arranged in one unity of land transportation management policy and economic 
growth of society. The effectiveness of land transportation management policy is highly dependent on how the Government has installed its land transportation management in terms of supply and demand. With appropriate management policies and including planning, organizing, implementing and controlling, ground transportation conditions are also expected to reach the target well(Kadarisman, Gunawan and Ismiyati, 2017)

The cost of shipping by train is still quite expensive. It is because the train is charged by the government. For every train passing its tracks or rails PT. KAI must pay a fee to the government. This is one factor that causes the cost of shipping by train to be expensive and makes PT.KAI always incurs loss every year. Whereas the train in Indonesia is only managed by PT.KAI which means the railway market in Indonesia is a monopoly market or does not have competition. The following is the trend of the use of trains from year to year.

\section{TREND \& PROYEKSI ANGKUTAN BARANG}

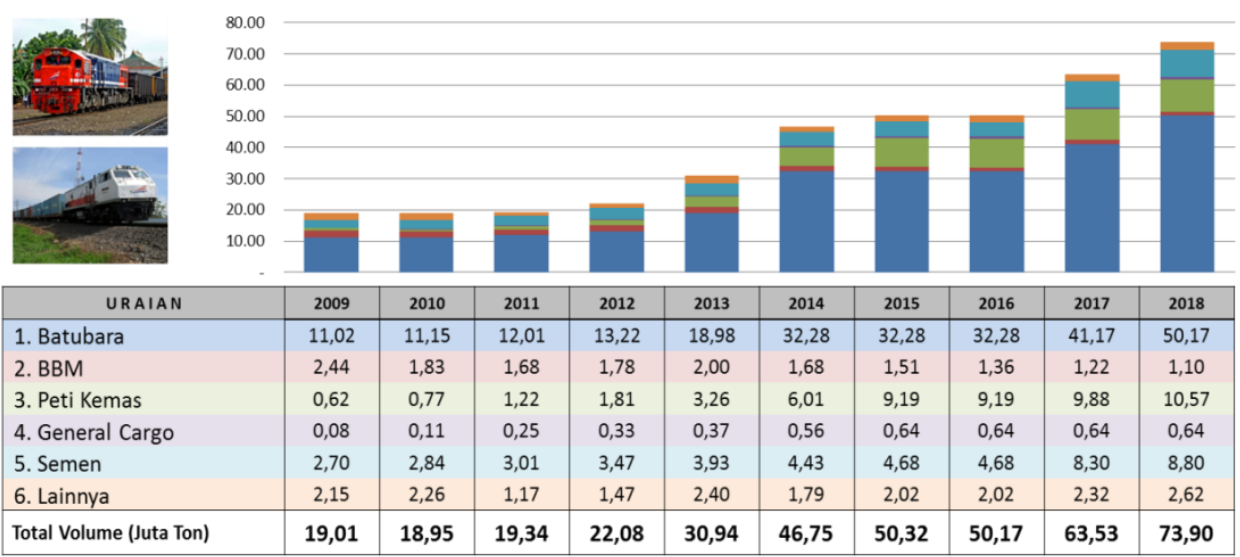

Figure 1. Trend \& Proyeksi Angkutan Barang

Based on the table, it can be concluded that coal becomes the main commodity that uses railway transport. From year to year the trend of transportation of coal by using train continues to increase. For general cargoes and containers themselves, it shows very small percentage, which means the delivery of containers and general cargo by train is still rarely desirable. This is quite reasonable because the delivery of containers and general cargo railway cannot do door-to-door service like trucks. However, 
when viewed from the other side, the time delivery by trucks for long distance will be much longer, and more expensive than using railway transport.

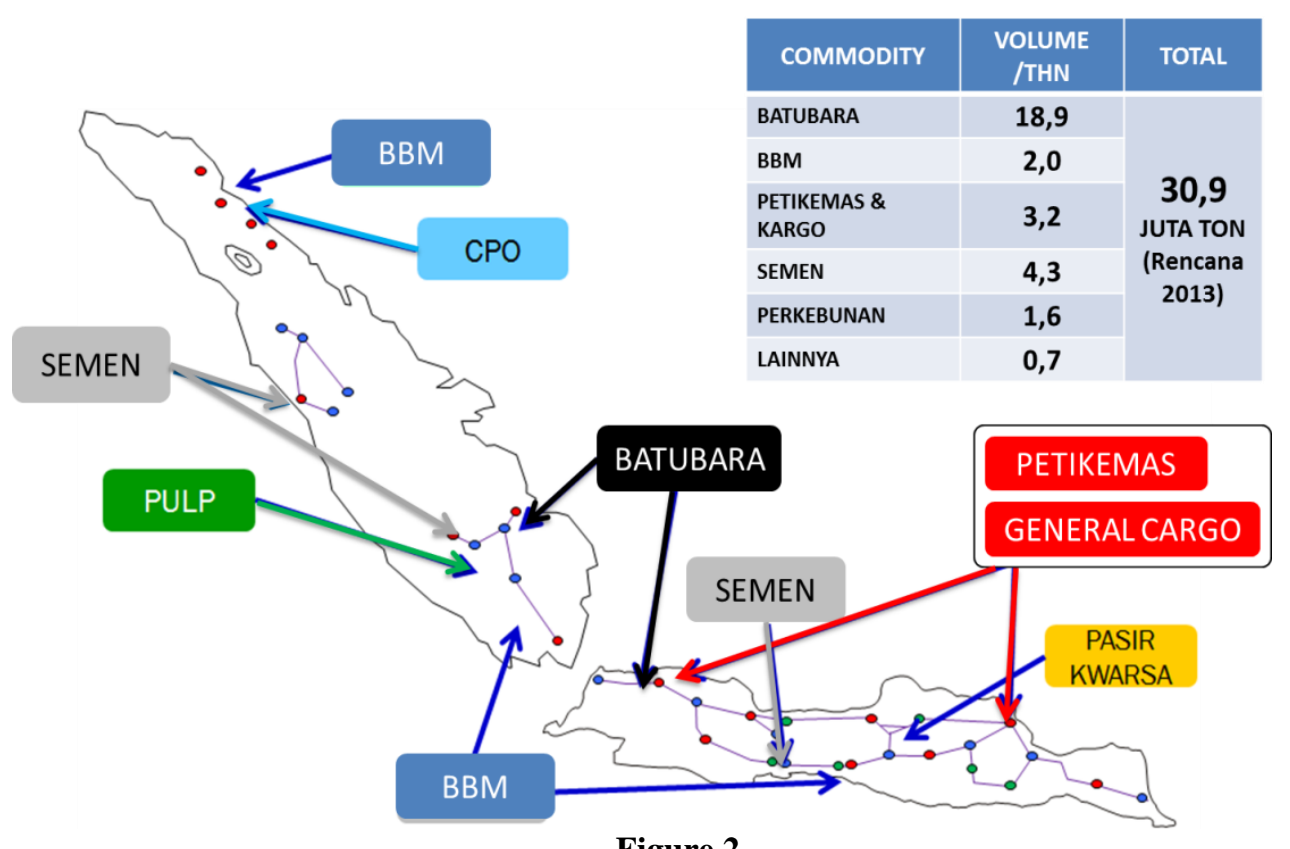

Figure 2.

In addition, truck transport delivery also has a high risk compared to trains, such as truck hijacking, illegal levies or illegal fees, accidents, etc. They can occur in transit using truck transport. Despite the high risk industry players and logistic services still rely on trucks for the transportation. In addition to the habit, the assumptions that the train is much more expensive and not necessarily effective and efficient are also taken into account. The reason why rail transport is not necessarily effective and efficient is because for example if industrial businessmen want to send automotive parts from Jakarta to Surabaya, then the businessman must prepare the vehicle to the station. After the destination, it must be loaded back to the truck to be transported to the place aim. This causes the business players to do more than they should and also incur additional costs.

1. Comparison of freight cost between train and truck

Shipping costs will affect an industrial company or logistics service in determining the choice of transportation modes used. The most cost- 
efficient or efficient will certainly be the choice of business players. In addition to reduce shipping, it purposes to increase corporate profits. The following is the comparison data of shipping:

Table 1.

Comparison of economic value

\begin{tabular}{|c|c|c|c|c|}
\hline & $\begin{array}{c}\text { Station to } \\
\text { station (JKT- } \\
\text { CDP) } \\
\text { Cikarang }\end{array}$ & $\begin{array}{c}\text { Door to door } \\
\text { (JKT-CDP) } \\
\text { Cikarang }\end{array}$ & $\begin{array}{r}\text { Station to } \\
\text { station CDP } \\
\text { Cikarang- } \\
\text { Surabaya }\end{array}$ & $\begin{array}{r}\text { Door to door } \\
\text { CDP } \\
\text { Cikarang- } \\
\text { Surabaya }\end{array}$ \\
\hline Truck \\
container & Rp.1.800.000 & Rp.1.800.000 & Rp.9.300.000 & Rp.9.300.000 \\
\hline Train & Rp.700.000 & Rp.2.550.000 & Rp.3.000.000 & Rp.7.510.000 \\
\hline Ships & - & - & Rp.4.200.000 & Rp.5.750.000 \\
\hline
\end{tabular}

Based on the table it can be concluded that delivery by train for below $350 \mathrm{Km}$ is much more expensive, especially for door-to-door service compared to using a truck. As seen on delivery of Jakarta to Cikarang Dry Port, using train with service between stations only charged Rp.700.000, but if the businessmen want to do delivery using door-to-door service then the cost will increase to Rp.2.550.000, -.

On the other hand, shipping by freight trains is much cheaper than trucks for shipping above $350 \mathrm{KM}$, such as shipping from cikarang to Surabaya by using freight trains for door-to-door service costs Rp.7.510.000, - whereas if using truck the cost is Rp.9.300.000, -. In addition to cheaper of course delivery by train is much faster and less risk of accident or other crimes. From the data it can be stated that the shipment by rail transport is not expensive and tends to be cheaper for shipping above $350 \mathrm{KM}$. Based on the data it can be deduced if the use of logistic railway in Indonesia has not supported the essence of supply chain, in this case it is cost savings (Othman and Abdul Ghani, 2008). 
1. Innovation that should be done by PT. Kereta Api Logistik

The current demand for logistics services is increasingly diverse, as the freight trains or commonly referred as logistics trains, the company's credibility largely determines the company's ability to cope with diverse demands and is able to provide rail services that can improve logistics efficiency. Here are the innovations that can be done by PT.KAI to be able to meet the increasingly diverse needs:

a) Modification of flat wagons for automotive and other commodity commodities.

To be able to absorb the opportunities of the railroad logistics that can innovate flat wagons. The picture below shows automotive commodities.
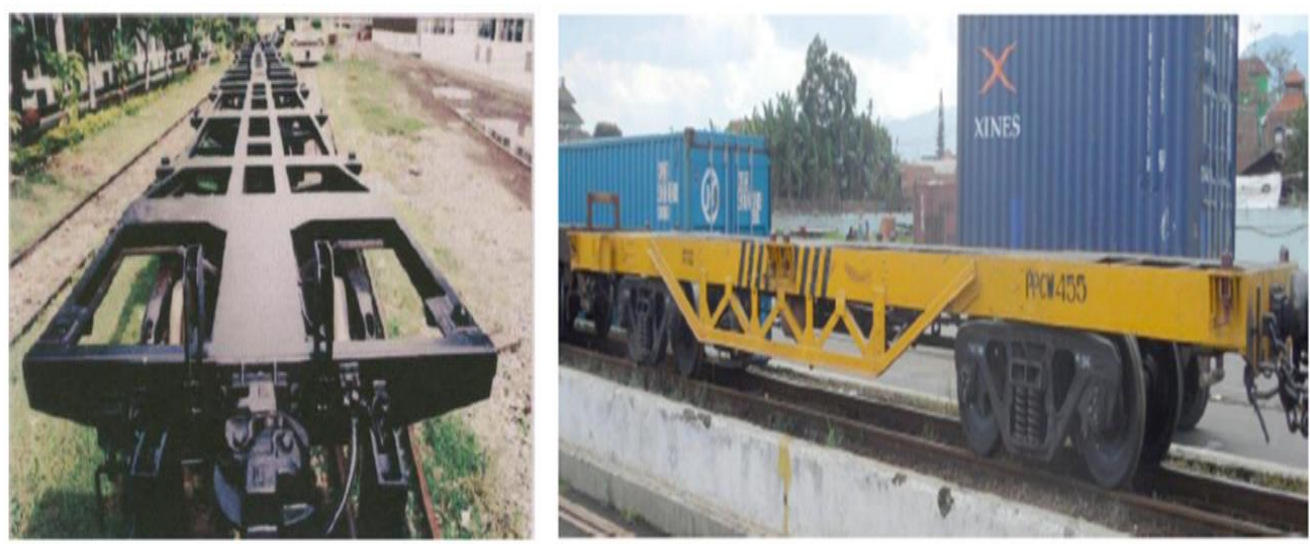

b) Adding capacity per wagon.

Currently the wagon capacity for freight trains is only 20 ton where one train journey can carry 20 frames of 20 feet. To attract consumers, PT.KALOG needs to increase the capacity of the wagon and the frame of mind that the current railway line is already double track, so it can transport more commodities in one trip.

c) Increas the capacity of the wagon circuit.

Currently PT.KAI already has plans to increase the capacity of the train in one trip. It needs to be realized because the need for logistics services is increasing.

d) Establish cooperation with trucking company 
Cooperation with the trucking company aims to make trains capable of providing door-to-door service to consumers. So far, the train has only a station-to-station service. With this cooperation, it is expected that the future of freight railway users will increase.

2. The Commitment of Government

In addition to optimize the innovations needed of freight rail transport to be efficiency, the role and commitment of government must exist and the government must consider the idealism dimension to adopt a policy as within the framework of green politics (Satiti, 2005). Logistics and industry players are willing to use freight transport goods for their distribution or logistics. The role of government to achieve its objectives can be done by making policies that regulate the use of trucking and railway transport. Such a policy for trucking as follows:

a. Prohibit old trucks from passing on the highway.

b. Apply high taxes on trucks.

c. Support the cooperation of trucking companies by train to work together to make cheap door-to-door service.

d. Limit the capacity or load that the truck can carry.

Policies for railway companies are indispensable in order that freight trains may be an option for consumers, such as the following policies:

a. Free pass for trains

b. Providing subsidies for freight trains so that shipping costs are cheaper

c. Supporting PT.KAI's plan for infrastructure improvement.

d. Expanding the rail network throughout Indonesia.

After given these policies, there will be many positive impacts if industry entrepreneurs want to use the railway, such as reducing road congestion, reducing accident rates, achieved logistics efficiency, road infrastructure will be much more durable, and etc.

3. Development of Railways to Ports and Industrial Zones 
The development of the railway that will enter the port area has been around for a long time. Now that, the development of railway line for port entrance has been realized, it is aimed that the logistics efficiency can be achieved. The increasing volume of containers makes no longer possible for all containers to be transported by truck. Then trains entering the port area will be the right solution to solve the problem. In addition it will reduce the number of congestion and the delivery time will be faster.

It would be great if government and PT.KAI develop the railway to the industrial areas. So that it is expected there is an integrated path between the port and industrial area in order to achieve the efficiency of logistics in integrated mode of transportation, such as rail lines from the industrial area to the port and vice versa.

Rail Network of Java:

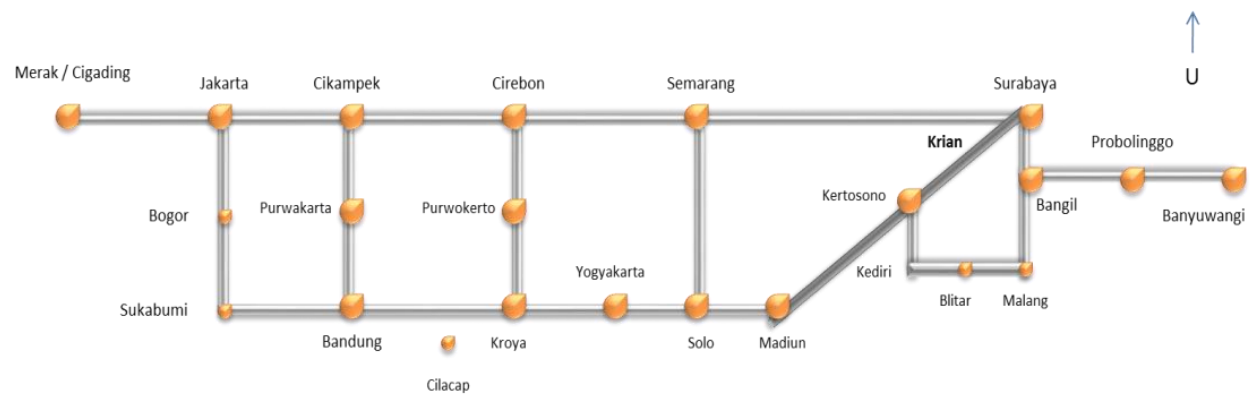

\begin{tabular}{|c|l|l|r|r|}
\hline NO & \multirow{2}{*}{ KOMODITI } & \multicolumn{1}{|c|}{ LINTAS } & $\begin{array}{c}\text { FREK/ } \\
\text { HARI }\end{array}$ & $\begin{array}{c}\text { KAPASITAS / } \\
\text { KA }\end{array}$ \\
\hline \multirow{2}{*}{1} & Petikemas & Jakarta - Surabaya & 10 KA PP & $40-60$ TEUs \\
& & Jakarta - Bandung & 2 KA PP & 24 TEUs \\
& & Jakarta - Cigading & 1 KA PP & 40 TEUs \\
\hline \multirow{2}{*}{2} & \multirow{2}{*}{ BBM } & Cilacap - Tegal & 2 KA & 600 Ton \\
& & Yogya - Madiun & 2 KA & 600 Ton \\
& & Surabaya - Malang & 1 KA & 600 Ton \\
& & Surabaya - Madiun & 1 KA & 600 Ton \\
\hline
\end{tabular}

\begin{tabular}{|c|l|l|r|r|}
\hline NO & KOMODITI & \multicolumn{1}{|c|}{ LINTAS } & $\begin{array}{c}\text { FREK/ } \\
\text { HARI }\end{array}$ & $\begin{array}{c}\text { KAPASITAS / } \\
\text { KA }\end{array}$ \\
\hline 3 & Batubara & Cigading - Bekasi & 3 KA & 600 Ton \\
\hline 4 & Semen & Cilacap - Yogya - Solo & 4 KA & 450 Ton \\
& & $\begin{array}{l}\text { Cilacap - Semarang } \\
\text { Cirebon - Purwokerto } \\
\text { Cirebon - Yogya }\end{array}$ & 1 KA & $\begin{array}{r}450 \text { Ton } \\
530 \text { Ton } \\
720 \text { Ton }\end{array}$ \\
\hline 5 & Cargo & Jakarta - Surabaya & 4 KA & 200 Ton \\
& & & & \\
\hline
\end{tabular}


Rail Network Of south Sumatera:

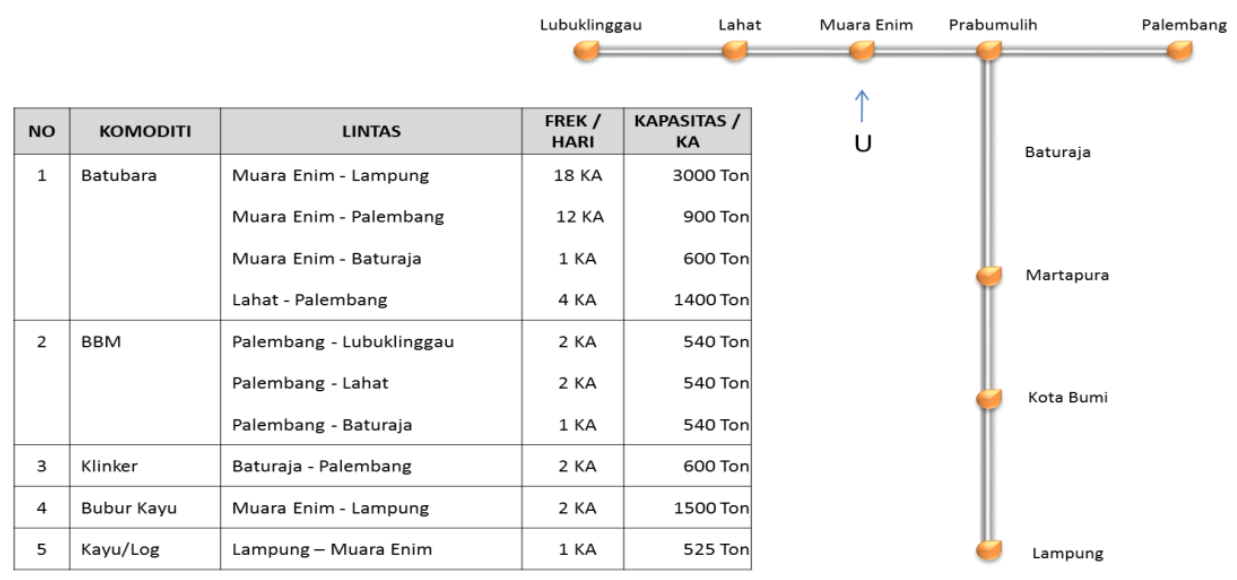

Rail Network of North Sumatera:

\begin{tabular}{|c|l|l|r|r|}
\hline NO & \multirow{2}{*}{ KOMODITI } & \multicolumn{1}{|c|}{ LINTAS } & $\begin{array}{c}\text { FREK / } \\
\text { HARI }\end{array}$ & $\begin{array}{c}\text { KAPASITAS / } \\
\text { KA }\end{array}$ \\
\hline \multirow{2}{*}{1} & CPO & Rantauprapat - Belawan & 6 KA & 360 Ton \\
& & Kisaran - Belawan & 2 KA & 360 Ton \\
& & Tebingtinggi - Belawan & 2 KA & 360 Ton \\
\hline 2 & \multirow{2}{*}{ BBM } & Medan - Kisaran & 1 KA & 360 Ton \\
& & Medan - Siantar & 1 KA & 360 Ton \\
\hline 3 & Lateks & Kisaran - Belawan & 2 KA & 360 Ton \\
\hline
\end{tabular}

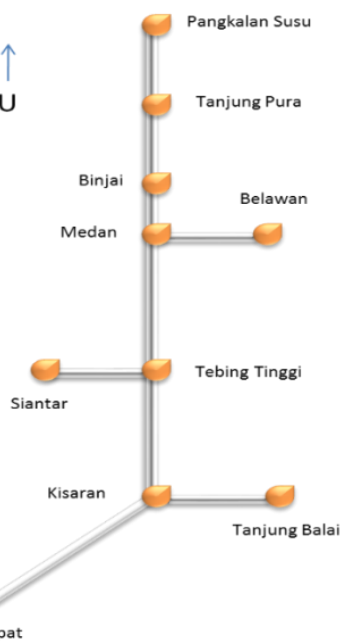

\section{Conclusion}

Freight trains are suitable modes of transportation used in shipping with distant distribution above $350 \mathrm{KM}$. Besides faster and cheaper, freight trains are also much safer than truck modes. An innovation is needed to increase logistics services in order to absorb the various opportunities. The government's commitment also needed to be shown to regulate this problem because everything will not be done properly without the commitment and policy of the government. Therefore, government commitment expressed in the form of policy is needed by the railway companie so that logistic and industrial service entrepreneurs are willing to use the freight service to 
achieve the logistics efficiency which becomes the main objective of national logistic system (SISLOGNAS).

The development of fire trails to ports and industrial estates should also be done by the government and PT.KAI in creating an integrated transportation. Because logistics efficiency requires an integrated transportation as it is the intent and purpose of the National Logistics System (SISLOGNAS).

\section{References}

Kadarisman, M., Gunawan, A. and Ismiyati, I. (2017) 'Kebijakan Manajemen Transportasi Darat Dan Dampaknya Terhadap Perekonomian Masyarakat Di Kota Depok', Jurnal Manajemen Transportasi Dan Logistik, 3(1), p. 41. doi: 10.25292/j.mtl.v3i1.140.

Rifni, M. and Prasetya, O. (2016) 'KERETA API LOGISTIK', pp. 405419.

Wibowo, F. P. (2016) 'Strategi persaingan usaha angkutan barang pt. kereta logistik', pp. 439-458.

Surabaya, M. and Satiti, D. S. (2005) 'Kebijakan Transportasi Publik dalam Perspektif Green Politics ( Studi tentang Rencana Pembangunan )', pp. 1-11.

Othman, R. and Abdul Ghani, R. (2008) 'Supply chain management and suppliers' HRM practice', Supply Chain Management: An International Journal, 13(4), pp. 259-262. doi: 10.1108/13598540810882143.

Kayikci, Y. (2010) 'A conceptual model for intermodal freight logistics centre location decisions', Procedia - Social and Behavioral Sciences, 2(3), pp. 6297-6311. doi: 10.1016/j.sbspro.2010.04.039.

Fred R. David. Strategic Management, Jakarta, 2009.

Kamus Populer Transportasi dan Logistik, Tim Penyusun STMT Trisakti, Jakarta 2012.

Ricky Martono. (2015). Manajemen Logistik Terintegrasi, Jakarta.

Robbins Stephen. (2004). Perilaku Organisasi, Jakarta.

Sugiyono. (2014). Metode Penelitian, Jakarta.

Syofian Siregar. (2004). Metode Penelitian, Jakarta. 